\title{
Effect of Various Anti-mycoplasma Drugs on Haemato-biochemical Changes in Mycoplasma synoviae Infected Broilers
}

\author{
Vijaykumar Matham ${ }^{1 *}$, A. Gopala Reddy ${ }^{2}$, Prakash Nadoor $^{1}$ and M. Ramakoti Reddy ${ }^{3}$ \\ ${ }^{1}$ Department of Veterinary Pharmacology and Toxicology, Veterinary College, \\ KVAFSU, Bidar $(K S)-585401$, India \\ ${ }^{2}$ Department of Veterinary Pharmacology and Toxicology, PV Narasimha RaoTelangana \\ State Veterinary University, Hyderabad (TS)-500048, India \\ ${ }^{3}$ Division of Animal Health, ICAR Directorate of Poultry Research, \\ Hyderabad (TS)-500048, India \\ *Corresponding author
}

\begin{abstract}
A B S T R A C T
The present study was conducted to evaluate the effect of various antimycoplasma drugs on haematological and biochemical changes in commercial broilers. Three hundred and twenty, day-old, unsexed broiler chicks of Vencobb strain were randomly allotted to 7 treatment groups with each treatment having 4 replicates and each replicate consisting of 10 birds. T1 served as negative control, T2-T7 groups were administered with Tylosin, Enrofloxacin, Taimulin, Erythromycin, Tilmicosin and Nizatidine whereas, T8 served as positive control group. Blood samples were collected from all the treatment groups for the estimation of haemato-biochemical profiles in mycoplasma affected broilers. Haematological examination revealed a significant increase in red blood cells, haemoglobin and packed cell volume in T7 group compared to T0. The AST levels in group T1 were significantly $(\mathrm{p}<0.05)$ higher as compared to group T2 and T6 but were significantly $(\mathrm{p}<0.05)$ lower at the end of $5^{\text {th }}$ wk compared to T0. The ALT, ALP levels were significantly $(p<0.05)$ lower at the end of $5^{\text {th }}$ week in all the groups. Total protein was significantly $(\mathrm{p}<0.05)$ higher in T2 to T7 as compared to other groups at the end of $5^{\text {th }}$ wk. All groups revealed significant $(\mathrm{p}<0.05)$ increase in albumin and globulin concentration on $5^{\text {th }}$ week as compared to $3^{\text {rd }}$ week. Thus, tylosin showed a significant restoration of haemato-biochemical parameters in Mycoplasma broilers followed by enrofloxacin, tiamulin, erythromycin, tilmicosin and nizatidine respectively.
\end{abstract}

\section{Introduction}

Mycoplasma synoviae (Ms), the smallest and simplest bacteria, is categorized as an atypical organism that lacks cell wall. It is a major pathogen of chicken and turkey, and causes respiratory tract infection and synovitis worldwide. Most of the damage resulting from Mycoplasma species infections in humans and animals is due to the host immune and inflammatory responses rather than the direct deadly effects of Mycoplasma 
virulence factors. Different Ms strains are characterized by differences in infectivity, tissue tropism and pathogenicity. Stipkovits (2000) has reported that- M. synoviae strains are becoming more resistant to antibiotics than other avian mycoplasmas, which means that it is more difficult to treat infected flocks successfully. Soon after antimicrobial drugs have been readily available for human and veterinary medicine usage, it was recognized that decreased bacterial susceptibility could adversely affect clinical outcome. This is no less true for the mycoplasmas. Increasing resistance of mycoplasmas against tetracyclines (TerLaak et al., 1993), macrolides (Chirstensen et al., 1985) and quinolones (Bebear et al., 1999) has been reported both in animal and human species. Antibiotics like tilmicosin and tylosin (Jordan et al., 1996), oxytetracycline, amino glycosides, lincosamides, fluoroquinolones and tiamulin (Bradbury et al., 1994 and Hannan et al., 1997) have been shown to possess different degrees of in vitro activity against various mycoplasma species. There is a variety of antibacterials available in market, but little data are available about its in vivo efficacy against local isolates of Ms. Hence the present study aimed to evaluate the antimycoplasmal efficacy of commercial drugs, namely tylosin, enrofloxacin, taimulin, erythromycin, tilmicosin and nizatidine, against Mycoplasma synoviae (Ms) infection in broiler chickens. Haemato-biochemical parameters were assessed in this study following the administration of these drugs to the Ms-challenged birds.

\section{Materials and Methods}

\section{Experimental birds and management}

Three hundred and twenty (320), day-old, unsexed broiler chicks of strain Vencobb were purchased from a local hatchery for this study and were randomly allotted to 8 treatment groups with each treatment having 4 replicates and each replicate having 10 birds. T1 served as negative control, T2-T7 groups were administered with Tylosin, Enrofloxacin, Taimulin, Erythromycin, Tilmicosin and Nizatidine whereas, T8 served as positive control group (Table 1).

The brooder house as-well-as other equipment were thoroughly disinfected before the arrival of the chicks and maintained as per the Cobb Broiler Management Guide (Cobb, 2008). Additional source of heat was provided during the brooding period. Birds of all the groups were vaccinated with Marek's Disease Vaccine (Day 1) New castle disease (ND) vaccine on $7^{\text {th }}$ and $21^{\text {st }}$ and $31^{\text {st }}$ day and infectious bursal disease (IBD) vaccine on $14^{\text {th }}$ day. During the first three weeks of trial, the chicks were fed adlibitum with standard starter mashand thereafter with finisher mash. Water at ambient temperature and diets (starter and finisher phases) were supplied adlibitum throughout the period (Table 2 and 3). All the birds from group T0-T7 were inoculated with $10^{4} \mathrm{ccu} / \mathrm{ml}$ of Ms Culture on day 16.

\section{Haemato-biochemical estimation}

Around 5ml of blood samples were collected from each replicate of birds at the end of $3^{\text {rd }}$ and $5^{\text {th }} \mathrm{wk}$ of the experimental period via brachial vein for the estimation of Haematobiochemical parameters. In haematological parameters, packed cell volume (\%), red blood cell count $\left(10^{6} / \mathrm{mm}^{3}\right), \quad \mathrm{MCH}(\mathrm{Pg})$, MCHC $(\%)$ and ESR $(\mathrm{mm} / \mathrm{h})$ were estimated on $3^{\text {rd }}$ and $5^{\text {th }}$ week.

Sera samples were analyzed on $3^{\text {rd }}$ and $5^{\text {th }}$ week for aspartate amino transferase, alanine aminotransferase, alkaline phosphatase, total proteinand albumin concentration using diagnostic kits (Swamed). 


\section{Results and Discussion}

\section{Hematological parameters}

The haematological parameters recorded on $3^{\text {rd }}$ and $5^{\text {th }}$ week are depicted in (Table 4 and 5). Hematological data on $3^{\text {rd }}$ week revealed that birds in $\mathrm{T} 7$ group had significantly higher number of circulating RBCs, packed cell volume and haemoglobin concentration $(1.92 \pm 0.14, \quad 31.95 \pm 0.19$ and $\quad 11.06 \pm 0.21)$ followed by T2 group $(1.82 \pm 0.21$, $30.51 \pm 0.11,12.85 \pm 0.12)$ as compared to as compared to T0 $(1.26 \pm 0.12,26.25 \pm 0.09$ and $10.15 \pm 0.10)$ group. Enrofloxacin still retains the acceptable advantage because it has broader spectrum of activity. On the contrary, Amer et al., (2012) reported tilmicosin to be effective in the treatment and prevention of CRD in broilers derived from positive breeders. Enrofloxacin is antibiotics belonging to the fluoroquinolone class of compounds. This drug is more potent than any earlier analogues, has a broad spectrum of activity and drug resistant bacteria are induced less frequently (Wolfson and Hooper, 1988).Non-significant changes in the haematological parameters of $\mathrm{T} 1, \mathrm{~T} 2, \mathrm{~T} 3, \mathrm{~T} 4$, T5, T6 and T7 group birds at the end of the $5^{\text {th }}$ week indicating a favorable response of the treatment as opined by Ibrahim (2004) on Mycoplasma synoviae infection.

\section{Biochemical parameters}

Mean \pm SE of biochemical parameters on $3^{\text {rd }}$ and $5^{\text {th }}$ week are presented in table 6 and 7 . The AST levels in the group T1 were significantly $(\mathrm{p}<0.05)$ higher as compared to group T2 and T6, but were significantly $(\mathrm{p}<0.05)$ lower at the end of $5^{\text {th }}$ wk compared toT0. The activity of serum ALT (IU/L) in groups $\mathrm{T} 0$ and $\mathrm{T} 1$ at end of $3^{\text {rd }}$ week was $33.22 \pm 12.04$ and $38.72 \pm 12.73$, which was significantly $(\mathrm{P}<0.05)$ higher compared to other groups. The group T2 showed a significant $(\mathrm{P}<0.05)$ increase, as compared to other groups at the end of $5^{\text {th }}$ week. AST is associated with cell necrosis of many different tissues, either muscular or hepatic cells. It has both cytoplasmic and mitochondrial isozymes and tends to be released more than the ALT in chronic hepatocellular diseases.

The ALT levels in the group T2 treated with enrofloxacin were significantly $(p<0.05)$ higher as compared to group $\mathrm{T} 0$ and $\mathrm{T} 7 \mathrm{but}$ were significantly $(\mathrm{p}<0.05)$ lower at the end of $5^{\text {th }}$ week compared to T6. Coles (1986) reported that the increase in the serum activity of ALT is directly related to the amount of the damaged hepatocytes.

The activity of serum ALP (IU/L) in group T0 at end of $3^{\text {rd }}$ week was $2761 \pm 0.31$, which was significantly $(\mathrm{P}<0.05)$ increased in treated groups. The ALP levels in the group T4 were significantly $(\mathrm{p}<0.05)$ higher as compared to groups $\mathrm{T} 1$ and $\mathrm{T} 2$, but were significantly $(p<0.05)$ lower at the end of $5^{\text {th }}$ week as compared toT0. The serum alkaline phosphatase activity was increased five to six time than the normal with hepatic diseases (Coles, 1986). In the present study, the therapeutic dose of enrofloxacin induced a significant increase in the activities of the AST, ALT and ALP at different weeks of age. The findings are attributed to a mild toxic effect of the drug metabolites, which increase the permeability of the cell membrane increasing hepatic enzymes. M. synoviae infection induced highly significant increase in AST and ALT in T0 group. The elevation of serum enzymes may be due to the increased cell membrane permeability and destruction besides necrosis of hepatic cells permitting the intracellular enzymes to escape to the extracellular compartment then to blood. Similar findings were also reported by El-Shabiny et al., (1984), Ramadan (1996) and Eisa (2001). A significant increase in the 
serum ALP in different groups at the 3rd and 5th week of age may be due to liver damage associated with mild hepatitis or due to increased activity of alkaline phosphatase in the synovial fluid by Mycoplasma synoviae infection resulting from alteration in capillary permeability that occur during the bacterimic phase of the disease as mentioned by ElShabiny (1984), Ramadan (1996) and Eisa (2001). The findings are in agreement with those previously recorded bylbrahim (2004) who stated that the enrofloxacin caused hepatic dysfunction. While at the end of the $5^{\text {th }}$ week, the activities of these enzymes nearly regained their normal values due to the cessation of the drug. The results are in accordance with those observed by Hillel (1988), Ramadan (1996), Ibrahim (2004) and El-Kadeem (2005), who reported that the enrofloxacin induced an elevation of the serum transaminase activities and AP during treatment. This elevation nearly restored its normal value after cessation of drug metabolites.

Table.1 In vivo experimental protocol for pharmacological evaluation of drugs against Ms

\begin{tabular}{|c|c|c|c|}
\hline S. No. & Group & $\begin{array}{l}\text { Birds/ } \\
\text { Group }\end{array}$ & Group treatment \\
\hline 1. & $\begin{array}{l}\mathbf{T}_{\mathbf{0}} \text { Negativeco } \\
\text { ntrol }\end{array}$ & 40 & $\begin{array}{l}\text { Control group T0 was fed standard basal ration } \\
\text { without any antibiotic/herbal medicine added to it } \\
\text { (inoculated with Ms Culture on Day 16) }\end{array}$ \\
\hline 2. & $\mathbf{T}_{1:}$ Treatment & 40 & $\begin{array}{l}\text { Tylosin dose@MIC value from Day 1-3;Day 16- } \\
\text { 18;Day 26-28, and Day 34-36 inoculated with Ms } \\
\text { Culture on Day } 16\end{array}$ \\
\hline 3. & $\mathbf{T}_{2: \text { Treatment }}$ & 40 & $\begin{array}{l}\text { Enrofloxacin dose @ MIC value; from Day } 1 \text { - } \\
\text { 3;Day 16-18;Day 26-28, and Day 34-36 } \\
\text { (inoculated with Ms Culture on Day 16) }\end{array}$ \\
\hline 4. & $\mathbf{T}_{3}$ :Treatment & 40 & $\begin{array}{l}\text { Taimulin dose @ MIC value; from Day 1-3;Day 16- } \\
\text { 18;Day 26-28, and Day 34-36 } \\
\text { (inoculated with Ms Culture on Day 16) }\end{array}$ \\
\hline 5. & $\mathbf{T}_{4:}$ Treatment & 40 & $\begin{array}{l}\text { Erythromycin dose @ MIC value; from Day 1- } \\
\text { 3;Day 16-18;Day 26-28, and Day 34-364 } \\
\text { (inoculated with Ms Culture on Day 16) }\end{array}$ \\
\hline 6. & $\mathbf{T}_{5: \text { Treatment }}$ & 40 & $\begin{array}{l}\text { Tilmicosin dose@MIC value; from Day 1-3;Day } \\
\text { 16-18;Day 26-28, and Day 34-36 } \\
\text { (inoculated with Ms Culture on Day 16) }\end{array}$ \\
\hline 7 & $\mathbf{T}_{6}:$ Treatment & 40 & $\begin{array}{l}\text { Nizatidine@MIC value; from Day 1-3;Day 16- } \\
\text { 18;Day 26-28, and Day 34-36 } \\
\text { (inoculated with Ms Culture on Day 16) }\end{array}$ \\
\hline 8 & $\begin{array}{l}\text { T }_{7}: \text { Postivecon } \\
\text { trol }\end{array}$ & 40 & $\begin{array}{l}\text { Positive Control group was fed standard basal } \\
\text { ration without any antibiotic/herbal medicine } \\
\text { added to it (Not inoculated with Ms Culture on Day } \\
\text { 16) }\end{array}$ \\
\hline
\end{tabular}


Table. 2 Composition of diets for broiler (starter and finisher phases)

\begin{tabular}{|l|c|c|}
\hline Ingredients & Starter phase $\mathbf{( \% )}$ & Finisher phase (\%) \\
\hline Maize & 46.00 & 50.00 \\
\hline Soybean meal & 18.50 & 12.00 \\
\hline Groundnut cake & 15.00 & 11.00 \\
\hline Fishmeal & 2.00 & 2.00 \\
\hline Wheat offal & 12.45 & 19.05 \\
\hline Bone meal & 2.00 & 2.00 \\
\hline Oyster shell & 3.00 & 3.00 \\
\hline Salt & 0.25 & 0.25 \\
\hline Premix & 0.25 & 0.25 \\
\hline Methionine & 0.30 & 0.25 \\
\hline Lysine & 0.25 & 0.20 \\
\hline
\end{tabular}

$* 1 \mathrm{~kg}$ of premix contains:

Vitamin A-10,000,000 IU; Vitamin D3-2,000,000; Vitamin E-20,000 IU;Vitamin K-2,250mg; Thiamine B11,750mg; Riboflavin B2- 5,000mg; Pyridoxine B6- 2,750mg; Niacin-27,500mg; Vitamin B12-15mg; Pantothenic acid- 7,500mg; Folic acid-7500mg; Biotin-50mg; Choline chloride-400g; Antioxidant-125g; Magnesium-80g; Zinc50mg; Iron-20g; Copper-5g; Iodine-1.2g; Selenium-200mg; Cobalt-200mg

Table.3 Nutritional Values of Feed used in the experiment

\begin{tabular}{|c|c|c|}
\hline Calculated & Starter phase & $\begin{array}{c}\text { Finisher } \\
\text { phase }\end{array}$ \\
\hline Crude protein(\%) & 23.05 & 19.91 \\
\hline M.E(Kcal/kg) & 2816 & 2809.6 \\
\hline Etherextract(\%) & 3.93 & 3.89 \\
\hline Crude fibre(\%) & 3.67 & 3.79 \\
\hline Calcium(\%) & 1.75 & 1.74 \\
\hline Phosphorus(\%) & 0.43 & 0.41 \\
\hline
\end{tabular}

Table.4 Effect of drug treatment on the hematological profiles in broiler chickens $\left(3^{\text {rd }}\right.$ week $)$

\begin{tabular}{|c|c|c|c|c|c|c|c|}
\hline & $\begin{array}{c}\text { RBC } \\
\left(\mathrm{x} 10^{6} / \mu \mathrm{L}\right)\end{array}$ & $\mathrm{PCV}(\%)$ & $\mathrm{Hb}(\mathrm{g} / \mathrm{dl})$ & $\mathrm{MCV}(\mathrm{fl})$ & $\mathrm{MCH}(\mathrm{Pg})$ & $\mathrm{MCHC}(\%)$ & $\mathrm{ESR}(\mathrm{mm} / \mathrm{h})$ \\
\hline T0 & $1.26 \pm 0.12^{\mathrm{a}}$ & $26.25 \pm 0.09^{\mathrm{a}}$ & $10.15 \pm 0.10^{\mathrm{ab}}$ & $116.23 \pm 0.09^{\mathrm{a}}$ & $42.05 \pm 0.10^{\mathrm{a}}$ & $33.93 \pm 0.09^{\mathrm{a}}$ & $1.32 \pm 0.11^{\mathrm{a}}$ \\
\hline T1 & $1.72 \pm 0.17^{\mathrm{b}}$ & $29.62 \pm 0.12^{\mathrm{b}}$ & $12.40 \pm 0.17^{\mathrm{ab}}$ & $122.72 \pm 0.11^{\mathrm{ab}}$ & $52.81 \pm 0.17^{\mathrm{b}}$ & $42.46 \pm 0.17^{\mathrm{b}}$ & $2.35 \pm 0.17^{\mathrm{b}}$ \\
\hline T2 & $1.82 \pm 0.21^{\mathrm{b}}$ & $30.51 \pm 0.11^{\mathrm{b}}$ & $12.85 \pm 0.12^{\mathrm{b}}$ & $120.98 \pm 0.08^{\mathrm{ab}}$ & $52.41 \pm 0.12^{\mathrm{b}}$ & $42.85 \pm 0.11^{\mathrm{b}}$ & $2.41 \pm 0.13^{\mathrm{b}}$ \\
\hline T3 & $1.76 \pm 0.13^{\mathrm{b}}$ & $29.96 \pm 0.17^{\mathrm{b}}$ & $12.67 \pm 0.19^{\mathrm{b}}$ & $126.68 \pm 0.12^{\mathrm{b}}$ & $54.41 \pm 0.11^{\mathrm{b}}$ & $42.81 \pm 0.13^{\mathrm{b}}$ & $2.33 \pm 0.09^{\mathrm{b}}$ \\
\hline T4 & $1.32 \pm 0.14^{\mathrm{a}}$ & $31.04 \pm 0.19^{\mathrm{ab}}$ & $10.15 \pm 0.21^{\mathrm{a}}$ & $116.23 \pm 0.07^{\mathrm{a}}$ & $42.05 \pm 0.13^{\mathrm{a}}$ & $33.93 \pm 0.11^{\mathrm{a}}$ & $1.32 \pm 0.14^{\mathrm{a}}$ \\
\hline T5 & $1.67 \pm 0.13^{\mathrm{b}}$ & $31.96 \pm 0.17^{\mathrm{b}}$ & $14.67 \pm 0.19^{\mathrm{b}}$ & $128.68 \pm 0.12^{\mathrm{b}}$ & $56.41 \pm 0.11^{\mathrm{b}}$ & $44.81 \pm 0.13^{\mathrm{b}}$ & $2.53 \pm 0.09^{\mathrm{b}}$ \\
\hline T6 & $1.70 \pm 0.17^{\mathrm{b}}$ & $27.62 \pm 0.12^{\mathrm{a}}$ & $13.40 \pm 0.17^{\mathrm{b}}$ & $112.72 \pm 0.11^{\mathrm{a}}$ & $48.81 \pm 0.17^{\mathrm{b}}$ & $48.46 \pm 0.17^{\mathrm{b}}$ & $1.75 \pm 0.17^{\mathrm{a}}$ \\
\hline T7 & $1.92 \pm 0.14^{\mathrm{b}}$ & $31.95 \pm 0.19^{\mathrm{ab}}$ & $11.06 \pm 0.21^{\mathrm{a}}$ & $117.14 \pm 0.07^{\mathrm{a}}$ & $42.96 \pm 0.13^{\mathrm{a}}$ & $34.84 \pm 0.11^{\mathrm{a}}$ & $2.23 \pm 0.14^{\mathrm{b}}$ \\
\hline
\end{tabular}

Means within a column with different subscripts differ significantly $(\mathrm{p}<0.05)$ 
Table.5 Effect of drug treatment on the hematological profiles in broiler chickens $\left(5^{\text {th }}\right.$ week)

\begin{tabular}{|c|c|c|c|c|c|c|c|}
\hline & $\begin{array}{c}\text { RBC } \\
\left(\mathrm{x} 10^{6} / \mu \mathrm{L}\right)\end{array}$ & $\mathrm{PCV}(\%)$ & $\mathrm{Hb}(\mathrm{g} / \mathrm{dl})$ & $\mathrm{MCV}(\mathrm{fl})$ & $\mathrm{MCH}(\mathrm{Pg})$ & $\mathrm{MCHC}(\%)$ & $\mathrm{ESR}(\mathrm{mm} / \mathrm{h})$ \\
\hline T0 & $1.37 \pm 0.12^{\mathrm{a}}$ & $32.4 \pm 0.09^{\mathrm{ab}}$ & $11.51 \pm 0.10^{\mathrm{a}}$ & $117.59 \pm 0.09^{\mathrm{a}}$ & $43.41 \pm 0.10^{\mathrm{a}}$ & $35.29 \pm 0.09^{\mathrm{a}}$ & $2.68 \pm 0.11^{\mathrm{b}}$ \\
\hline T1 & $2.27 \pm 0.21^{\mathrm{b}}$ & $30.96 \pm 0.11^{\mathrm{a}}$ & $13.3 \pm 0.12^{\mathrm{b}}$ & $121.43 \pm 0.08^{\mathrm{b}}$ & $52.86 \pm 0.12^{\mathrm{b}}$ & $43.3 \pm 0.11^{\mathrm{b}}$ & $2.86 \pm 0.13^{\mathrm{b}}$ \\
\hline T2 & $2.17 \pm 0.17^{\mathrm{b}}$ & $30.07 \pm 0.12^{\mathrm{a}}$ & $12.85 \pm 0.17^{\mathrm{b}}$ & $123.17 \pm 0.11^{\mathrm{b}}$ & $53.26 \pm 0.17^{\mathrm{b}}$ & $42.91 \pm 0.17^{\mathrm{b}}$ & $2.8 \pm 0.17^{\mathrm{b}}$ \\
\hline T3 & $2.21 \pm 0.13^{\mathrm{b}}$ & $30.41 \pm 0.17^{\mathrm{a}}$ & $13.12 \pm 0.19^{\mathrm{b}}$ & $127.13 \pm 0.12^{\mathrm{b}}$ & $54.86 \pm 0.11^{\mathrm{b}} 43.26 \pm 0.13^{\mathrm{b}}$ & $2.78 \pm 0.09^{\mathrm{b}}$ \\
\hline T4 & $1.46 \pm 0.14^{\mathrm{a}}$ & $31.49 \pm 0.19^{\mathrm{ab}}$ & $10.6 \pm 0.21^{\mathrm{a}}$ & $116.68 \pm 0.07^{\mathrm{a}}$ & $42.5 \pm 0.13^{\mathrm{a}}$ & $34.38 \pm 0.11^{\mathrm{a}}$ & $1.77 \pm 0.14^{\mathrm{a}}$ \\
\hline T5 & $2.12 \pm 0.13^{\mathrm{b}}$ & $32.41 \pm 0.17^{\mathrm{a}}$ & $15.12 \pm 0.19^{\mathrm{b}}$ & $129.13 \pm 0.12^{\mathrm{b}}$ & $56.86 \pm 0.11^{\mathrm{b}} 45.26 \pm 0.13^{\mathrm{b}}$ & $2.98 \pm 0.09^{\mathrm{b}}$ \\
\hline T6 & $2.15 \pm 0.17^{\mathrm{b}}$ & $28.07 \pm 0.12^{\mathrm{a}}$ & $13.85 \pm 0.17^{\mathrm{b}}$ & $113.17 \pm 0.11^{\mathrm{a}}$ & $49.26 \pm 0.17^{\mathrm{b}}$ & $48.91 \pm 0.17^{\mathrm{b}}$ & $2.2 \pm 0.17^{\mathrm{b}}$ \\
\hline T7 & $1.46 \pm 0.14^{\mathrm{a}}$ & $31.49 \pm 0.19^{\mathrm{ab}}$ & $10.6 \pm 0.21^{\mathrm{a}}$ & $116.68 \pm 0.07^{\mathrm{a}}$ & $42.5 \pm 0.13^{\mathrm{a}}$ & $34.38 \pm 0.11^{\mathrm{a}}$ & $1.77 \pm 0.14^{\mathrm{a}}$ \\
\hline
\end{tabular}

Means within a column with different subscripts differ significantly $(\mathrm{p}<0.05)$

Table.6 Effect of drug treatment via water on biochemical profiles in broiler chickens ( ${ }^{\text {rd }}$ week)

\begin{tabular}{|c|c|c|c|c|c|c|c|c|}
\hline Parameter & T0 & T1 & T2 & T3 & T4 & T5 & T6 & T7 \\
\hline $\operatorname{AST}\left(\mathbf{U}^{-1}\right)$ & $18.31 \pm 2.74^{b}$ & $23.46 \pm 2.07^{\mathrm{a}}$ & $10.98 \pm 2.02^{b}$ & $13.19 \pm 2.19^{b}$ & $13.19 \pm 2.11^{\mathrm{b}}$ & $14.71 \pm 3.33^{\mathrm{b}}$ & $21.82 \pm 2.84^{\mathrm{b}}$ & $18.28 \pm 3.87^{\mathrm{ab}}$ \\
\hline $\operatorname{ALT}\left(\mathbf{U}_{\mathbf{L}}{ }^{-1}\right)$ & $33.22 \pm 12.04^{\mathrm{ab}}$ & $38.72 \pm 12.73^{\mathrm{a}}$ & $26.20 \pm 8.94^{b}$ & $19.97 \pm 7.69^{\mathrm{ab}}$ & $19.97 \pm 7.69^{\mathrm{ab}}$ & $20.22 \pm 13.19^{\mathrm{ab}}$ & $38.94 \pm 7.21^{\mathrm{a}}$ & $24.2 \pm 7.57^{b}$ \\
\hline $\operatorname{ALP}\left(U^{\prime} \mathbf{L}^{-1}\right)$ & $2761 \pm 0.31^{\mathrm{a}}$ & $3149 \pm 0.22^{b}$ & $3033 \pm 0.12^{b}$ & $3407 \pm 0.27^{b}$ & $3741.13 \pm 0.14^{b}$ & $3033 \pm 0.12^{b}$ & $3407 \pm 0.27^{b}$ & $2341.13 \pm 0.14^{a}$ \\
\hline $\begin{array}{l}\text { Albumin } \\
(\mathrm{mg} / 100 \mathrm{ml})\end{array}$ & $20.86 \pm 3.63^{b}$ & $22.263 \pm 2.00 \mathrm{ab}$ & $20.59 \pm 2.71^{b}$ & $20.11 \pm 6.18^{b}$ & $19.19 \pm 3.37^{b}$ & $17.42 \pm 1.75^{\mathrm{b}}$ & $21.33 \pm 4.53^{\mathrm{a}}$ & $21.54 \pm 2.70^{\mathrm{a}}$ \\
\hline $\begin{array}{l}\text { Serum globulin } \\
(\mathrm{mg} / 100 \mathrm{ml})\end{array}$ & $31.73 \pm 8.10^{b}$ & $44.51 \pm 12.18^{\mathrm{ab}}$ & $41.18 \pm 7.42^{\mathrm{ab}}$ & $40.22 \pm 9.69^{\mathrm{a}}$ & $38.37 \pm 6.78^{\mathrm{ab}}$ & $34.84 \pm 8.63 \mathrm{a}^{\mathrm{b}}$ & $42.66 \pm 6.26^{\mathrm{a}}$ & $43.08 \pm 5.80^{\mathrm{a}}$ \\
\hline $\begin{array}{l}\text { Serum total } \\
\text { protein }(\mathrm{mg} / 100 \\
\text { ml) }\end{array}$ & $52.59 \pm 9.31^{\mathrm{a}}$ & $66.77 \pm 13.35^{\mathrm{a}}$ & $61.72 \pm 8.74^{\mathrm{a}}$ & $60.33 \pm 4.71^{\mathrm{a}}$ & $57.56 \pm 9.02^{\mathrm{a}}$ & $52.26 \pm 9.68^{\mathrm{a}}$ & $63.99 \pm 6.88^{\mathrm{ab}}$ & $64.62 \pm 5.34^{\mathrm{a}}$ \\
\hline A:G ratio & 1.50 & 2.00 & 2.00 & 2.00 & 2.00 & 2.00 & 2.00 & 2.00 \\
\hline
\end{tabular}

Means within a row with different subscripts differ significantly $(\mathrm{p}<0.05)$

Table.7 Effect of Drug Treatment via water on Biochemical profiles in Broiler chickens $\left(5^{\text {th }}\right.$ week)

\begin{tabular}{|c|c|c|c|c|c|c|c|c|}
\hline Parameter & T0 & T1 & T2 & T3 & T4 & T5 & T6 & $\mathbf{T 7}$ \\
\hline $\operatorname{AST}\left(\mathbf{U ~ L ~}^{-1}\right)$ & $28.63 \pm 3.74^{\mathrm{ab}}$ & $33.78 \pm 3.07^{\mathrm{a}}$ & $21.30 \pm 3.02^{b}$ & $23.51 \pm 2.90^{\mathrm{ab}}$ & $23.51 \pm 2.90^{\mathrm{ab}}$ & $25.03 \pm 4.33^{\mathrm{ab}}$ & $32.14 \pm 2.84^{\mathrm{ab}}$ & $28.60 \pm 3.87^{\mathrm{ab}}$ \\
\hline $\operatorname{ALT}\left(\mathbf{U ~ L}^{-1}\right)$ & $43.45 \pm 2.04^{\mathrm{ab}}$ & $48.95 \pm 2.73^{\mathrm{a}}$ & $16.20 \pm 8.94^{b}$ & $30.20 \pm 7.69^{\mathrm{ab}}$ & $30.20 \pm 7.69^{\mathrm{ab}}$ & $30.45 \pm 3.19^{\mathrm{ab}}$ & $49.17 \pm 7.21^{\mathrm{a}}$ & $14.2 \pm 7.57^{b}$ \\
\hline $\operatorname{ALP}\left(\mathrm{U} \mathrm{L}^{-1}\right)$ & $2690 \pm 0.23^{c}$ & $2085.23 \pm 0.21^{\mathrm{a}}$ & $2185.23 \pm 0.26^{b}$ & $2275.23 \pm 0.09^{b}$ & $2481.29 \pm 0.19^{c}$ & $2185.23 \pm 0.26^{b}$ & $2275.23 \pm 0.09^{b}$ & $2081.29 \pm 0.19^{c}$ \\
\hline $\begin{array}{l}\text { Albumin } \\
(\mathrm{mg} / 100 \mathrm{ml})\end{array}$ & $27.50 \pm 3.63^{b}$ & $28.80 \pm 3.00^{\mathrm{ab}}$ & $28.80 \pm 2.71^{b}$ & $26.79 \pm 6.18^{\mathrm{a}}$ & $32.16 \pm 3.37^{\mathrm{ab}}$ & $33.63 \pm 1.75^{\mathrm{ab}}$ & $27.93 \pm 4.53^{\mathrm{ab}}$ & $28.13 \pm 2.70^{a}$ \\
\hline $\begin{array}{l}\text { Serum globulin } \\
(\mathrm{mg} / 100 \mathrm{ml})\end{array}$ & $50.77 \pm 8.10^{\mathrm{ab}}$ & $63.65 \pm 12.18^{\mathrm{ab}}$ & $53.65 \pm 7.42^{\mathrm{ab}}$ & $59.22 \pm 9.69^{b}$ & $71.08 \pm 6.78^{\mathrm{ab}}$ & $74.31 \pm 8.63^{\mathrm{a}}$ & $61.74 \pm 6.26^{\mathrm{ab}}$ & $62.17 \pm 5.80^{\mathrm{a}}$ \\
\hline $\begin{array}{l}\text { Serum total } \\
\text { protein } \\
(\mathrm{mg} / 100 \mathrm{ml})\end{array}$ & $78.27 \pm 9.31^{\mathrm{a}}$ & $92.45 \pm 13.35^{\mathrm{a}}$ & $82.45 \pm 8.74^{\mathrm{a}}$ & $86.01 \pm 4.71^{\mathrm{a}}$ & $103.24 \pm 9.02^{\mathrm{a}}$ & $107.94 \pm 9.68^{a}$ & $89.67 \pm 6.88^{a}$ & $90.3 \pm 5.34^{a}$ \\
\hline A/G Ratio & 1.85 & 2.21 & 1.86 & 2.21 & 2.21 & 2.21 & 2.21 & 2.21 \\
\hline
\end{tabular}

Means within a row with different subscripts differ significantly $(\mathrm{p}<0.05)$ 
The concentration of total protein $(\mathrm{mg} / 100 \mathrm{ml})$ of the group T0 was significantly $(\mathrm{p}<0.05)$ lower $\left(52.59 \pm 9.31\right.$ and $78.27 \pm 9.31$ during $3^{\text {rd }}$ and $5^{\text {th }} \mathrm{wk}$, respectively) than those of group T7 $\left(64.62 \pm 5.34\right.$ and $90.3 \pm 5.34$ during $3^{\text {rd }}$ and $5^{\text {th }} \mathrm{wk}$, respectively). The concentration of albumin $(\mathrm{mg} / 100 \mathrm{ml})$ of the group T0 was significantly $(\mathrm{p}<0.05)$ lower $(20.86 \pm 3.63$ and $27.50 \pm 3.63$ during $3^{\text {rd }}$ and $5^{\text {th }} \mathrm{wk}$, respectively) than those of group T7 $(21.54 \pm 2.70$ and $28.13 \pm 2.70$ during $3^{\text {rd }}$ and $5^{\text {th }} \mathrm{wk}$, respectively). The groups $\mathrm{T} 3$ to $\mathrm{T} 6$ showed significant $(\mathrm{p}<0.05)$ increase in albumin concentration as compared to group $\mathrm{T} 0$ at the end of $5^{\text {th }} \mathrm{wk}$. The concentration of globulins $(\mathrm{mg} / 100 \mathrm{ml})$ of the group T0 was significantly $(\mathrm{p}<0.05)$ lower $(31.73 \pm 8.10$ and $27.50 \pm 3.63$ during $3^{\text {rd }}$ and $5^{\text {th }} \mathrm{wk}$, respectively) than those of group T7 $(21.54 \pm 2.70$ and $50.77 \pm 8.10$ during $3^{\text {rd }}$ and $5^{\text {th }} \mathrm{wk}$, respectively). The groups 3 to 6 showed significant $(p<0.05)$ increase in globulin concentration as compared to group T0 at the end of $5^{\text {th }} \mathrm{wk}$. The groups T3 to T7 showed significantly $(\mathrm{p}<0.05)$ higher globulin concentration as compared to group $\mathrm{T} 2$ at the end of $5^{\text {th }} \mathrm{wk}$. The values of groups T3 and T6 (40.22 \pm 9.69 and 42.66 \pm 6.26 , respectively) were comparable to that of group $\mathrm{T} 7$ at the end of $5^{\text {th }}$ wk. The A/G ratio of T0 group was significantly $(\mathrm{p}<0.05)$ lower $(1.50 \pm 0.13$ and $1.85 \pm 0.22$ during $3^{\text {rd }}$ and $5^{\text {th }} \mathrm{wk}$, respectively) than those of group T7 $(2.00 \pm 0.09$ and 2.21 \pm 0.03 during $3^{\text {rd }}$ and $5^{\text {th }}$ wk, respectively). All the treated groups ( 3 to 7 ) were comparable to that of group $\mathrm{T} 7$ at the end of $3^{\text {rd }}$ and $5^{\text {th }} \mathrm{wk}$.

The chickens of all the groups showed hyperglobulinaemia which led to hyperproteinaemia. The results are in accordance with Eisa (2001). The hyperglobulinaemia may be due to the immunodefence of the chickens against the microorganism. Similar results were described by Coles (1986). Hypoalbuminaemia was encountered at the end of the 5th week only, it may be attributed to inflammation and destruction in the liver, which is the main source of albumin synthesis in the body as previously mentioned. On the other hand, Eisa (2001) recorded nonsignificant changes in the albumin in 10 day old chickens, infected with Mycoplasma synoviae. This result agrees with that obtained in the 3 rd week. M. synoviae infection did not affect the renal tissues. The findings are in agreement with Ramadan (1996) and Ibrahim (2004). The present study showed that the treated groups induced non-significant changes in the total proteins, albumin and globulin at the end of the $3^{\text {rd }}$ and $5^{\text {th }}$ weeks. This result may be due to the mild and reversible effect of the drug on the liver. The results agree with those observed by Ibrahim (2004). On the other hand, with reference to group T2 our findings agree with Ibrahim (2004) and El- Kadeem (2005). They mentioned that the enrofloxacin induced hypoproteinaemia, hypoalbuminaemia or increase in the total proteins, albumin and globulin. Non- significant change in albumin in $\mathrm{T} 1, \mathrm{~T} 2$ and $\mathrm{T} 3$ compared with $\mathrm{T} 0$ at the end of the $5^{\text {th }}$ week indicating a favorable response to the treatment. Similar results were previously obtained by Ibrahim (2004). The used enrofloxacin in the present study affected the renal tissue leading to some renal damage which agrees with Wang et al., (2001). Thus, enrofloxacin showed the significant restoration of haematobiochemical parameters in Mycoplasma broilers followed by tylosin, tiamulin, erythromycin, tilmicosin and nizatidine.

\section{References}

Amer, M.M., Zohair, G.A., M. EL-Bayomi. and Zeinab, M. S.2012. Effect of Tilmicosin in Control of Mycoplasmosis in Broiler Chickens from Infected Breeders Using Elisa Test for Evaluation. Journal of American 
Science. 8(3): 696-700.

Bébéar, C. M., Renaudin, J. A., Charron, H., Renaudin, B., de Barbeyrac, T., Schaeverbeke. and Bébéar, C. 1999. Mutations in the gyrA, parC and par E genes associated with fluoroquinolones resistance in clinical isolates of Mycoplasma hominis. Antimicrobial Agents Chemotherapy. 43: 954-956.

Bradbury, J.M., Yavari, C.A., Giles, C.J. 1994. In vitro evaluation of various antimicrobial against mycoplasma gallisepticum and mycoplasma synoviae by the micro-broth method and comparison with a commercially prepared system. Avian Pathology. 23: 105-15.

Christensen, G. D., Simpson, W.A., Younger, J. J., Baddour, L. M., Barrett, F. F., Melton, D. M. and Beachey, E.H. 1985. Adherence of coagulase-negative staphylococci to plastic tissue culture plates: a quantitative model for the adherence of staphylococci to medical devices. Journal of Clinical Microbiology. 22: 996-1006.

Cobb-Vantress. 2008. Broiler management guide.

Coles, E. H. 1986. Veterinary Clinical Pathology. Edn. $4^{\text {th }}$., London, UK. WB Saunders Company.

Eisa, A. M. A. 2001. Clinicopathological studies on the effect of aivlosin as antimycoplasmal drug in chickens. $\mathrm{PhD}$ Thesis. Clinical Pathology Department. Faculty of Veterinary Medicine, Zag University.

El-Kadeem, A. E. M. 2005. Pharmacological studies of gentamicin and ciprofloxacin in collibacillosis in chickens. M.V.Sc. Thesis, Pharmacology Department. Faculty of Veterinary Medincine, Zag University.

El-Shabiny, L. M. 1984. Serum proteins and enzymatic changes in association with Mycoplasma Synoviae infection in poultry. Ph.D. Thesis, Biochemistry Department. Faculty of Veterinary Medicine. Zag University.

Hannan, P. T. C., Windsor, G.D., de Jong, A., Schmeer, N., Stegemann, M. 1997. Comparative susceptibilities of various animal-pathogenes mycoplasmas to fluoroquinolones. Antimicrobial Agents Chemotherapy. 41: 2037-40.

Hillel, H. 1988. Adverse effects of fluoroquinolones. Reviews in Infectious Diseases. 10: 258-261.

Ibrahim, M. A. K. 2004. Interaction between danofloxacin and isoflurpredoneactetate in chickens. M.V.Sc. Thesis, Pharmacology Dept. Faculty of Veterinary Medicine, Zag. University.

Jordan, F.T.W. and Horrocks, B.K. 1996. The minimum inhibitory concentration of tilmicosin and tylosin for Mycoplasma gallisepticum and Mycoplasma synoviae and a comparison of their efficacy in the control of Mycoplasma gallisepticum infection in broiler chicks. Avian Diseases. 40: 326-34.

Minion, F. C. and Kapke, P. A. 1998. Transformation of mycoplasmas. Methods in Molecular Biology-Clifton Then Totowa. 104: 227-234.

Ramadan, O. E. 1996. Some pharmacological studies on danofloxacin in chickens. PhD Thesis, Pharmacology Department. Faculty of Veterinary Medicine. Zag University.

Stipkovits, L., Ripley, P. H., Varga, J. and Palfi, V. 2000. Use of valnemulin in the control of Mycoplasma bovis infection under field conditions. Veterinary Record. 148: 399-402.

TerLaak, E. A., Noordergraaf, J. H. and Verschure, M. H. 1993. Susceptibilities of Mycoplasma bovis, Mycoplasma dispar and Ureaplasma diversum strains to antimicrobial agents in vitro. Antimicrobial Agents Chemotherapy. 37:317-321. 
Wang, C., Ewing, M. and A'arabi, S. Y. 2001. In vitro susceptibility of avian mycoplasmas to enrofloxacin, sarafloxacin, tylosin and oxytetracycline. Avian Disease.45: 456460

Wolfson, J.S., and Hooper, D.C. 1985. The fluoroquinolones: structures, mechanisms of action and resistance, and spectra of activity in vitro.
Antimicrobial. Agents Chemother. 28(4): 581-586.

Yalçin, S., Önenç, A., Özkan, S., Güler, H.C. and Siegel, P. B. (2005). Meat quality of heat stressed broilers: Effects of thermal conditioning at pre- and postnatal stages. XVIIth Eur. Symp. Qual. Poult. Meat. Doorwert, The Netherlands. WPSA, Beekbergen, The Netherlands.

\section{How to cite this article:}

Vijaykumar Matham, A. Gopala Reddy, Prakash Nadoor and Ramakoti Reddy, M. 2020. Effect of Various Anti-mycoplasma Drugs on Haemato-biochemical Changes in Mycoplasma synoviae Infected Broilers. Int.J.Curr.Microbiol.App.Sci. 9(08): 2092-2100.

doi: https://doi.org/10.20546/ijcmas.2020.908.238 